\title{
Mitigating Disease Impacts in Amphibian Populations: Capitalizing on the Thermal Optimum Mismatch Between a Pathogen and Its Host
}

\author{
Attila Hettyey ${ }^{1,2 *}$, János Ujszegi ${ }^{1}$, Dávid Herczeg ${ }^{1}$, Dóra Holly ${ }^{1,3}$, Judit Vörös ${ }^{4}$, \\ Benedikt R. Schmidt ${ }^{5,6}$ and Jaime Bosch ${ }^{7,8}$ \\ ${ }^{1}$ Lendület Evolutionary Ecology Research Group, Centre for Agricultural Research, Plant Protection Institute, Hungarian \\ Academy of Sciences, Budapest, Hungary, ${ }^{2}$ Department of Ecology, Institute for Biology, University of Veterinary Medicine, \\ Budapest, Hungary, ${ }^{3}$ Department of Systematic Zoology and Ecology, Eötvös Loránd University, Budapest, Hungary, \\ ${ }^{4}$ Department of Zoology, Hungarian Natural History Museum, Budapest, Hungary, ${ }^{5}$ Department of Evolutionary Biology and \\ Environmental Studies, University of Zurich, Zurich, Switzerland, ${ }^{6}$ Info Fauna Karch, UniMail, Neuchâtel, Switzerland, ${ }^{7}$ Museo \\ Nacional de Ciencias Naturales, Consejo Superior de Investigaciones Cientificas, Madrid, Spain, ${ }^{8}$ Research Unit of \\ Biodiversity - Consejo Superior de Investigaciones Científicas/Oviedo University/PA, Universidad de Oviedo, Mieres, Spain
}

OPEN ACCESS

Edited by:

Susan C. Walls,

United States Geological Survey,

United States

Reviewed by:

Jason Robert Rohr,

University of South Florida,

United States

Reid Harris,

James Madison University,

United States

${ }^{*}$ Correspondence:

Attila Hettyey

hettyey.attila@agrar.mta.hu

Specialty section

This article was submitted to Behavioral and Evolutionary Ecology,

a section of the journa

Frontiers in Ecology and Evolution

Received: 22 February 2019

Accepted: 18 June 2019

Published: 03 July 2019

Citation:

Hettyey A, Ujszegi J, Herczeg D, Holly D, Vörös J, Schmidt BR and Bosch J (2019) Mitigating Disease Impacts in Amphibian Populations: Capitalizing on the Thermal Optimum Mismatch Between a Pathogen and Its Host. Front. Ecol. Evol. 7:254.

doi: 10.3389/fevo.2019.00254
Understanding how animal behavior can influence the susceptibility of endangered hosts to emerging pathogens and using this knowledge to ameliorate negative effects of infectious wildlife diseases is a promising avenue in conservation biology. Chytridiomycosis, an emerging infectious disease caused by the fungal pathogen Batrachochytrium dendrobatidis $(B d)$ in amphibians has led to the most spectacular disease-borne loss of vertebrate biodiversity ever recorded in history. Unfortunately, the methods of mitigation that are available today are only practical in captive populations, and an effective method that could be applied in natural habitats without inflicting vast collateral damage is lacking. We suggest here that the thermal tolerance mismatch between $B d$ and its ectothermic hosts coupled with the thermoregulatory behavior of amphibians could be exploited in mitigation interventions combating $B d$ infection in situ. If microhabitats with elevated temperatures are made available in their natural environment, individuals taking advantage of the possibility to reach their preferred body temperature could critically lower their infection intensity or even clear the pathogen. We provide a basis for studying this approach by reviewing the evidence that supports the idea, describing how technical difficulties may be overcome, pointing out gaps in our knowledge that need to be filled by future studies, and listing presumable benefits and probable limitations of localized heating. The proposed approach has good potential to become an effective in situ mitigation method that can be easily employed in a wide taxonomic range of amphibians, especially in species that are warm-adapted, while causing less collateral damage than any other method that is currently available. If so, it may quickly become a widely applicable tool of biodiversity conservation and may contribute to saving many amphibian populations and species from extinction in the next few decades.

Keywords: Batrachochytrium dendrobatidis, Batrachochytrium salamandrivorans, emerging infectious disease, heated shelter, mitigation, thermal tolerance 


\section{INTRODUCTION}

Emerging infectious diseases of wildlife pose a serious threat to biodiversity. They can have large economic costs via spillover to livestock and, if zoonotic, they may also threaten human health (Daszak et al., 2000). Chytridiomycosis is an emerging infectious disease caused by the chytrid fungus Batrachochytrium dendrobatidis $(B d)$ in amphibians, where it has already led to the decline or extinction of hundreds of species (Skerratt et al., 2007; Wake and Vredenburg, 2008; Lips, 2016; Scheele et al., 2019). Chytridiomycosis continues to be one of the largest conservation issues because it is still spreading, it is highly virulent, and no widely applicable solution is in sight (Woodhams et al., 2011; Scheele et al., 2014, 2019; Garner et al., 2016). What makes this disease especially worrying is that it affects amphibians, which have been declining for decades and are already one of the most severely threatened vertebrate groups today (Houlahan et al., 2000; Stuart et al., 2004; Wake and Vredenburg, 2008), with $41 \%$ of species listed at least as threatened (IUCN, 2016).

Several lineages of $B d$ have been described (O'Hanlon et al., 2018), some of which have existed locally at least for decades without causing mass mortalities, but one hypervirulent lineage, $B d G P L$, has spread throughout the world in recent years and caused extinctions across several continents (Farrer et al., 2011; James et al., 2015; Lips, 2016; O'Hanlon et al., 2018; Scheele et al., 2019). Spread is attributable to two main factors: human activities (especially transportation and animal husbandry; Weldon et al., 2004; Garner et al., 2006; Scheele et al., 2019) and natural processes (primarily via migrating animals, including nonamphibians carrying the fungus; Vredenburg et al., 2010; Garmyn et al., 2012; McMahon et al., 2013). When $B d$ arrives to a new area, it can spread in a wave-like front, often leading to local extinctions or resulting in sharp declines and leaving just dwindling remnants of amphibian populations (Rachowicz et al., 2005; Lips et al., 2008; Cheng et al., 2011). Moreover, due to climate change, or the appearance of new, more virulent lineages, $B d$ can also suddenly become devastating in locations where it has previously not led to disease outbreaks (Bosch et al., 2007; Rödder et al., 2010; Clare et al., 2016; Jenkinson et al., 2016; Cohen et al., 2018). Furthermore, these two mechanisms leading to mass mortalities in amphibians are not mutually exclusive and may act in concert (Fisher et al., 2009; Rohr and Raffel, 2010; Walker et al., 2010; Lips, 2016; Cohen et al., 2018, 2019).

$B d$ infects keratinous skin surfaces of amphibians (Berger et al., 1998). In larval amphibians, $B d$ infection usually causes only mild symptoms, including lethargy and poor swimming performance resulting in somewhat lowered body mass, but larval mortality due to chytridiomycosis is rare (Blaustein et al., 2005; Garner et al., 2009; Hanlon et al., 2015). In metamorphs and adults, clinical signs of the disease can include thickening of the outermost skin layer, reddening, ulceration and excessive shedding of the skin, lethargy and anorexia (Berger et al., 1998, 2005). Chytridiomycosis impairs breathing and osmoregulation, facilitates co-infection by other infectious agents, may induce immunopathology, and can ultimately lead to cardiac arrest (Voyles et al., 2009; Campbell et al., 2012; Whitfield et al., 2013).
Several mechanisms of defenses against infectious agents exist in amphibians. Individuals of many species excrete antimicrobial peptides (AMPs) onto their skin and these have been shown to depress $B d$ infection loads in vitro (Woodhams et al., 2007a; Rollins-Smith, 2009). However, some species possessing AMPs are highly susceptible to infection (e.g., Rollins-Smith et al., 2006, 2009), and many species lack AMPs completely (Conlon et al., 2009). The adaptive immune system of amphibians may also contribute to the suppression of chytridiomycosis, but results are mixed in this respect as well (Rollins-Smith et al., 2009; Ramsey et al., 2010; Stice and Briggs, 2010; Cashins et al., 2013; McMahon et al., 2014). Individuals may adopt behavioral patterns that prevent infection or lower pathogen burden (i.e., "behavioral fever"; Kluger, 1977; Sherman et al., 1991; Lefcort and Blaustein, 1995; Sherman, 2008; Rakus et al., 2017), but the number of studies reporting such behavioral alterations in response to $B d$ has remained very limited (Murphy et al., 2011; Karavlan and Venesky, 2016; but also see Han et al., 2008; Sauer et al., 2018). Finally, some symbiotic bacteria inhabiting amphibian skin produce antifungal metabolites that can hamper colonization by $B d$ and reduce its growth (Harris et al., 2006, 2009a,b; Lam et al., 2010, 2011). However, symbionts are not ubiquitous (Lam et al., 2010), their performance is environmentdependent (Daskin et al., 2014), and they do not protect against all $B d$ lineages (Antwis et al., 2015). Despite these variable and sometimes powerful defenses, many amphibian populations and species are threatened by chytridiomycosis and are likely to persist only if we implement effective measures against this deadly disease.

Several countermeasures to chytridiomycosis have been proposed as a result of intense research focusing on the biology of $B d$, its interactions with amphibian hosts, and the factors influencing infection probability and disease progression (for reviews see Woodhams et al., 2011; Scheele et al., 2014; Garner et al., 2016). These include the application of salt and antifungals (Johnson et al., 2003; White, 2006; Pessier, 2008; Heard et al., 2014; Woodward et al., 2014; Bosch et al., 2015; Stockwell et al., 2015; Hudson et al., 2016; Geiger et al., 2017), the addition of probiotics (Woodhams et al., 2007b; Harris et al., 2009a; Muletz et al., 2012), immunization (Ramsey et al., 2010; McMahon et al., 2014), selection for $B d$-tolerance in captive-bred populations (Garner et al., 2016), enhancement of the density of microscopic aquatic predators of $B d$ zoospores (Buck et al., 2011; Searle et al., 2013; Schmeller et al., 2014), general actions facilitating population persistence and recovery (Muths et al., 2011; Shoo et al., 2011; Heard et al., 2014), and elevating the temperature in the environment of infected individuals (Woodhams et al., 2003; Chatfield and Richards-Zawacki, 2011; Heard et al., 2014; Scheele et al., 2015). Indeed, some of these approaches proved to be highly effective when applied in captive populations. However, because of high costs of maintaining populations in captivity, only a few dozen species may be saved ex situ (Zippel et al., 2011), so that mitigation approaches suitable for treating infected amphibian populations in their natural habitats are needed (Scheele et al., 2014; Garner et al., 2016). Unfortunately, the methods listed above are in their current form not yet suitable for in situ application. They are either 
associated with vast collateral damage to the environment, may also harm amphibians, are impractical outside the laboratory, are associated with immense costs, are simply not effective under natural conditions, or their use cannot be permitted because of nature conservation legislation (Scheele et al., 2014; Garner et al., 2016). Consequently, a feasible mitigation strategy for lowering the threat posed by chytridiomycosis in natural populations is still lacking (Scheele et al., 2014, 2019; Garner et al., 2016).

Finding a suitable strategy for mitigation, including those mentioned above, will require further intense research into the basic ecology of the pathogen and of its interactions with amphibian hosts, but may contribute to saving hundreds of amphibian species from extinction. Our aim here is to draw attention to a presumably effective, safely applicable and rather simple method of in situ mitigation that conservation managers may readily employ in the fight against chytridiomycosis. We outline the basic idea, list evidence providing support for its potential, describe how it could be realized technically, point out knowledge gaps that need to be filled before its application, list presumable benefits and probable limitations, and thereby provide a basis for researching this promising approach.

\section{A SUGGESTION FOR FIGHTING BD IN SITU}

We suggest exploiting the difference in the thermal optima and maxima between $B d$ and its amphibian hosts in their natural environment simply by providing opportunities for amphibians to reach their preferred body temperature. According to in vitro studies, the optimal temperature for $B d$ is around $20^{\circ} \mathrm{C}$, it grows well below $24^{\circ} \mathrm{C}$, and its critical thermal maximum $\left(\mathrm{CT}_{\max }\right)$ is around $28^{\circ} \mathrm{C}$ (Johnson et al., 2003; Piotrowski et al., 2004; Stevenson et al., 2013; Cohen et al., 2017; Voyles et al., 2017; also see Table 1). However, a global dataset on physiological heat tolerance comprising relevant data on 91 amphibian species suggests that the $\mathrm{CT}_{\max }$ is higher than $32^{\circ} \mathrm{C}$ in ca. $80 \%$ of amphibian species and lower than $30^{\circ} \mathrm{C}$ in just $7 \%$ (lower than $28^{\circ} \mathrm{C}$ in just one species; see supplementary dataset in Sunday et al. (2014a); also see Ultsch et al., 1999; Gutiérrez-Pesquera et al., 2016). Importantly, $\mathrm{CT}_{\max }$ strongly depends on age (Sherman and Levitis, 2003; Turriago et al., 2015) and it is weakly related to altitude and latitude while the phylogenetic footprint is significant (Sunday et al., 2014a,b; Gutiérrez-Pesquera et al., 2016). Nonetheless, exposure to temperatures of $28-30^{\circ} \mathrm{C}$ for a few days only will not be hazardous to a large number of amphibian species, but caution needs to be applied in case of cold-adapted species (see below). If the $\mathrm{CT}_{\max }$ of the targeted species, or at least of closely related species is known, it will be possible to set wide enough safety margins on the temperatures to be applied. Elevated temperatures can directly kill $B d$ zoospores and cells encysted in amphibian skin and sporangia. In addition, the immune function of amphibians and the antifungal activity of symbiotic bacteria living on amphibian skin may also increase toward higher temperatures (Raffel et al., 2006; Rollins-Smith et al., 2011; Daskin et al., 2014), especially in warm-adaptedspecies (Cohen et al., 2017, 2019; Sauer et al., 2018). These mechanisms may act synergistically, lowering the need for exposure of individuals to high temperatures for a prolonged time period (Table 1). In cold-adapted species the effectiveness of the immune system may decrease more quickly with increasing temperature than the performance of $B d$, resulting in relatively low temperature optima for the hosts (Cohen et al., 2017, 2018, 2019; Sauer et al., 2018). Because these cold-adapted species may not endure temperatures that surpass the $\mathrm{CT}_{\max }$ of $B d$, applying elevated temperatures may be counterproductive in their case. Consequently, it is important to first assess temperature preferences and critical thermal maxima of the species to be treated and thereafter apply heating, where the applied temperature should ideally surpass the $\mathrm{CT}_{\max }$ of $B d$, which is around $28^{\circ} \mathrm{C}$ (Table 1). The use of ambient temperatures elevated to $28-30^{\circ} \mathrm{C}$ may thereafter be a safe and effective way of treating amphibians infected by $B d$ (Berger et al., 2010; Woodhams et al., 2011; Scheele et al., 2014).

Several lines of evidence provide ample support for the potential of the in situ chytridiomycosis-mitigatory use of elevated temperatures. A good number of studies report successful clearing of $B d$-infection or at least significant lowering of infection prevalence and intensity in captive populations after application of elevated temperatures (Table 1). In addition, infection may be prevented in the first place by a warm environment (e.g., Blooi et al., 2015). Also, theoretical models and empirical studies on $B d$-prevalence and infection load revealed that both increase toward cooler areas and cooler periods of the year in tropical as well as in temperate climate zones (Retallick et al., 2004; Woodhams and Alford, 2005; Kriger et al., 2007; Walker et al., 2010; Forrest and Schlaepfer, 2011; Puschendorf et al., 2011; Fernández-Beaskoetxea et al., 2015; Gabor et al., 2015). These patterns are in accord with reports that in the tropics and subtropics, chytridiomycosis can have devastating effects in cool areas, like highlands, but much less so in warmer lowlands (e.g., Retallick et al., 2004; La Marca et al., 2005; Lips et al., 2006, 2008; Pounds et al., 2006; Walker et al., 2010; Rodríguez-Brenes et al., 2016), and during cool winter months, but much less during warmer parts of the year (Bradley et al., 2002; Berger et al., 2004). It is worth noting, however, that while some species suffer extreme population declines due to chytridiomycosis, others are little affected. This variation in the susceptibility to chytridiomycosis may partly be due to interspecific differences in the effectiveness of the immune system. However, species-, population- and sex-specific thermal profiles may also play a role: individuals that more often experience temperatures higher than $25^{\circ} \mathrm{C}$ are less likely to carry $B d$ (Rowley and Alford, 2013; Stevenson et al., 2014). Hence, elevating environmental temperatures beyond $25^{\circ} \mathrm{C}$ or, preferably, to $28-30^{\circ} \mathrm{C}$ may help amphibians keep $B d$-infection intensities low or even clear the infection, and, thus, may be an effective strategy of chytridiomycosis-mitigation (Berger et al., 2010; Woodhams et al., 2011; Scheele et al., 2014).

If elevated temperatures are so effective in lowering $B d$ prevalence and -loads, why has this approach not been applied so far in natural populations? A plausible explanation may be the apparently vast energy demand. Heating up the aquatic environment of larval amphibians to a high enough temperature and also maintaining this temperature would 
TABLE 1 | The effectiveness of elevated environmental temperature applied against Bd as reported by experiments performed on laboratory cultures of the fungus (in vitro studies) and on live and infected amphibians (in vivo experiments).

\begin{tabular}{|c|c|c|c|}
\hline Type of experiment & Treatment & Effectiveness & References \\
\hline In vitro & 28 or $29^{\circ} \mathrm{C}$ for 14 days & lowered $\mathrm{Bd}$-growth at $28^{\circ} \mathrm{C}$, no growth at $29^{\circ} \mathrm{C}$ & Longcore et al., 1999 \\
\hline In vitro & $32^{\circ} \mathrm{C}$ for 4 days $\mathrm{OR} 37^{\circ} \mathrm{C}$ for $4 \mathrm{~h}$ & Bd wipeout in $100 \%$ of cultures & Johnson et al., 2003 \\
\hline In vitro & $30^{\circ} \mathrm{C}$ for 8 days & Bd wipeout in $50 \%$ of cultures & Piotrowski et al., 2004 \\
\hline In vitro & $26,5^{\circ} \mathrm{C}$ for 8 days & no zoospore release & Woodhams et al., 2008 \\
\hline In vitro & $33^{\circ} \mathrm{C}$ for $1 \mathrm{~h}$ daily & lowered Bd growth & Daskin et al., 2011 \\
\hline In vitro & $23,25,26,27$, or $28^{\circ} \mathrm{C}$ for 14 days & lowered $\mathrm{Bd}$ growth beyond $26^{\circ} \mathrm{C}$ & Stevenson et al., 2013 \\
\hline In vitro & 26,27 , or $28^{\circ} \mathrm{C}$ constantly & no $B d$-growth beyond $28^{\circ} \mathrm{C}$ & Cohen et al., 2017 \\
\hline In vitro & $26^{\circ} \mathrm{C}$ for $4 \mathrm{~h}$ daily & lowered $B d$ growth & Greenspan et al., 2017a \\
\hline In vitro & 26,27 , or $28^{\circ} \mathrm{C}$ constantly & lowered $\mathrm{Bd}$-growth at $27^{\circ} \mathrm{C}$, no growth at $28^{\circ} \mathrm{C}$ & Voyles et al., 2017 \\
\hline In vivo & $37^{\circ} \mathrm{C}$ for $8 \mathrm{~h}$ on two consecutive days & clearance of $B d$ from $100 \%$ of juvenile frogs & Woodhams et al., 2003 \\
\hline In vivo & $27^{\circ} \mathrm{C}$ for 98 days & clearance of $\mathrm{Bd}$ from $50 \%$ of juvenile frogs & Berger et al., 2004 \\
\hline In vivo & $32^{\circ} \mathrm{C}$ for 5 days & clearance of $B d$ from $100 \%$ of adult frogs & Retallick and Miera, 2007 \\
\hline In vivo & 17 or $22^{\circ} \mathrm{C}$ constantly & $\begin{array}{l}\text { enhanced survival of juvenile frogs (from } 5 \text { to } 50 \% \text { ) } \\
\text { at } 22^{\circ} \mathrm{C}\end{array}$ & Andre et al., 2008 \\
\hline In vivo & $26^{\circ} \mathrm{C}$ for 42 days & reduced growth of $B d$ on adult frogs & Ribas et al., 2009 \\
\hline In vivo & 17 or $23^{\circ} \mathrm{C}$ constantly & $\begin{array}{l}\text { enhanced survival of adult frogs (from } 7 \text { to } 81 \% \text { ) at } \\
23^{\circ} \mathrm{C} \text {, at exposure to low zoospore density }\end{array}$ & Bustamante et al., 2010 \\
\hline In vivo & $30^{\circ} \mathrm{C}$ for 10 days & clearance of $B d$ from $96 \%$ of adult frogs & $\begin{array}{l}\text { Chatfield and Richards-Zawacki, } \\
2011\end{array}$ \\
\hline In vivo & $26^{\circ} \mathrm{C}$ for 5 days $\mathrm{OR} 30^{\circ} \mathrm{C}$ for $8+8+43 \mathrm{~h}$ & clearance of $B d$ from 63 to $88 \%$ of tadpoles & Geiger et al., 2011 \\
\hline In vivo & temperature increased from 15 to $18^{\circ} \mathrm{C}$ & doubling of time to death in juvenile toads & Murphy et al., 2011 \\
\hline In vivo & $30^{\circ} \mathrm{C}$ for $12 \mathrm{~h}+35^{\circ} \mathrm{C}$ for $24 \mathrm{~h}$ & ineffective in clearing $B d$ from adult frogs & Woodhams et al., 2012 \\
\hline In vivo & $30^{\circ} \mathrm{C}$ for 11 days & clearance of $B d$ from $100 \%$ of adult frogs & McMahon et al., 2014 \\
\hline In vivo & 22,26 , or $28^{\circ} \mathrm{C}$ constantly & growth of $\mathrm{Bd}$ ceases at around $28^{\circ} \mathrm{C}$ in adult frogs & Cohen et al., 2017 \\
\hline In vivo & $29^{\circ} \mathrm{C}$ for $4 \mathrm{~h} /$ day & clearance of $B d$ after 68 days from adult frogs & Greenspan et al., 2017a \\
\hline In vivo & 20,23 , or $26^{\circ} \mathrm{C}$ for ca. 90 days & $\begin{array}{l}\mathrm{Bd} \text { load at } 23 \text { and } 26^{\circ} \mathrm{C} \text { one order of magnitude } \\
\text { lower than at } 20^{\circ} \mathrm{C} \text { in adult frogs }\end{array}$ & Sonn et al., 2017 \\
\hline In vivo & $26^{\circ} \mathrm{C}$ for 63 days & lowered $B d$ load and elevated survival in adult frogs & $\begin{array}{l}\text { Robak and Richards-Zawacki, } \\
2018\end{array}$ \\
\hline
\end{tabular}

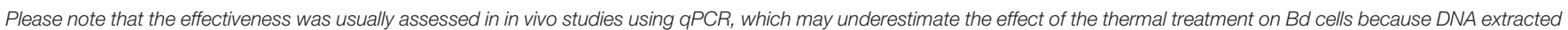
from dead cells may still be intact enough to amplify, resulting in false positives.

require a power input that can realistically not be provided in the wild in water bodies exceeding just a few $\mathrm{m}^{3}$ in size (ca. $12 \mathrm{kWh}$ necessary for each $\mathrm{m}^{3}$ of water just to increase the temperature by $10^{\circ} \mathrm{C}$; calculated as $W(\mathrm{kWh})=$ $\left\{V(l) \times c\left(k J / \mathrm{kg}^{\circ} \mathrm{C}\right) \times \Delta T\left({ }^{\circ} \mathrm{C}\right) / 3600\right\}$, where $V$ is the water volume, $c$ is the specific heat of water, $\Delta T$ is the change in temperature). In the terrestrial environment of adults, on the other hand, animals live dispersed, so that heating up their entire habitat is obviously absolutely impossible. Decreasing canopy cover around ponds and streams may lead to elevated temperatures and thereby provide sufficiently warm thermal refuges in many environments (Raffel et al., 2010; Geiger et al., 2011; Heard et al., 2014), but the approach of felling or pruning trees and shrubs may often not be an acceptable measure due to the collateral damage inflicted, especially so in protected areas, and removal of shading vegetation may simply not elevate temperatures to a sufficient extent in many others.

The obstacle of a vast energy demand can, however, be circumvented in many amphibians, especially in pond-breeding species, by applying localized heating: amphibians may be provided with localities where they can reach their preferred body temperatures also during times and at places where this would otherwise be impossible. It is not necessary to heat up the entire water body, its immediate surroundings or large areas that cover the terrestrial habitat, because if individuals are provided with warm spots, they will use these thanks to their inherent warmth-searching drive (e.g., Heath, 1975; Wilbur, 1980; Dupré and Petranka, 1985). Larvae, juveniles and adults of anuran amphibians are known to select warm areas in their natural habitat (e.g., shallow areas of ponds and sun-lit spots on land) and generally select temperatures between 26 and $30^{\circ} \mathrm{C}$ (Wells, 2007), while urodelans prefer somewhat lower temperatures ranging from 18 to $26^{\circ} \mathrm{C}$, depending on species and on developmental stage (e.g., Licht and Brown, 1967; Heath, 1975; Hutchison and Hill, 1976; Dupré and Petranka, 1985; Fontenot and Lutterschmidt, 2011). Because of their fossorial life history, thermal preferences in caecilians (Gymnophiona) are not well-understood, but $\mathrm{Bd}$ has also not been detected in this group yet. Consequently, individuals of many anuran species are likely to readily occupy areas with artificially elevated temperatures. 


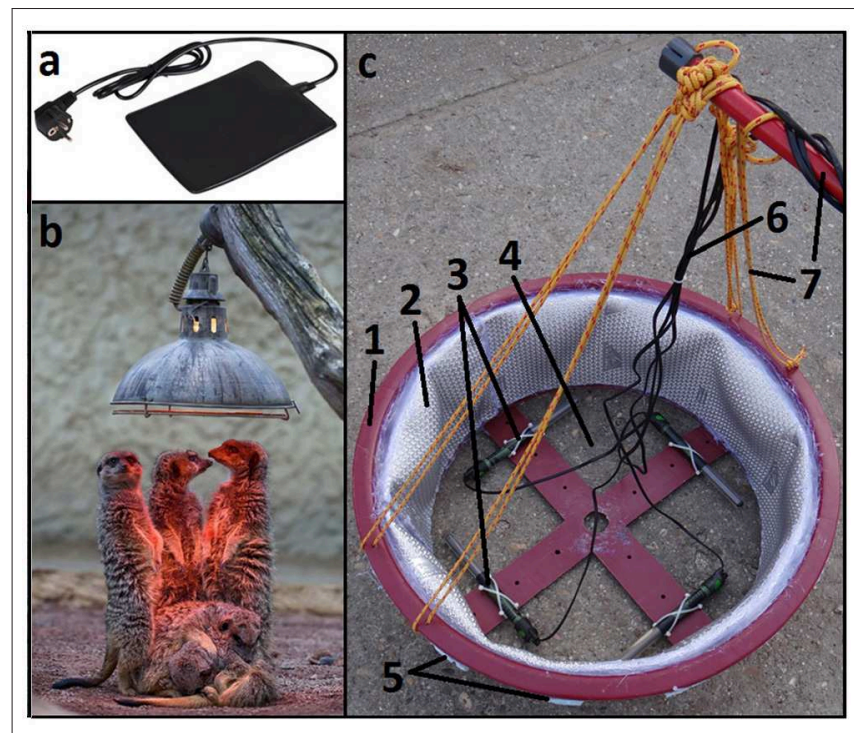

FIGURE 1 | Appliances that may be used for the realization of localized heating: (a) heat mat, (b) infrared heat lamp, as employed also for mammals in zoos (San Diego Zoo in this case), and (c) submersible heater [prototype: (1) skirting preventing heat dissipation via conductance; (2) insulation; (3) aquarium heaters fixed to bottom of appliance; (4) bottom with holes allowing amphibian larvae to enter warm spot; (5) swimmers under the upper edge stabilizing appliance and keeping it afloat; (6) electric cables; and (7) suspension facilitating in-pond placement of appliance].

If individuals can assess their $B d$-infection status and use warmer locations when necessary (i.e., behavioral fever; Murphy et al., 2011; Karavlan and Venesky, 2016), the effectiveness of localized heating may further be enhanced. Breeding adults, aquatic larvae and newly metamorphosed individuals could be targeted relatively easily in most species, because they occur aggregated both in time and space. Also, amphibians contract $B d$ during these water-dependent events or life stages, and the disease most often leads to mass-mortality shortly after metamorphosis (Van Rooij et al., 2015). Hence, lowering disease transmission rates and infection loads in larvae, metamorphs and reproducing adults using localized heating is likely possible in many species, and this is a plausible objective for any in situ chytridiomycosis mitigation method.

The technical realization of localized heating is simple in theory. In the terrestrial environment artificial shelters built around thermostat-controlled heat mats (e.g., $20 \times 20 \mathrm{~cm}$, consuming $10 \mathrm{~W}$ ) or infrared heat lamps (e.g., effectively lit area of $0.1 \mathrm{~m}^{2}$ at a consumption of $100 \mathrm{~W}$ ), as applied by terrarists and home gardeners, may be used (Figure 1). Heated terrestrial shelters may be dispersed around breeding ponds to target adults and freshly metamorphosed individuals leaving the water. In the aquatic environment, submersible aquarium heaters can be used to locally elevate water temperature. Heat dissipation through convection poses a problem here, but this can be overcome using an insulated skirting around heaters, which helps contain the warm water, but allows amphibians to enter from below (e.g., submersible heaters consuming just $500 \mathrm{~W}$ are sufficient to elevate the water temperature by $15^{\circ} \mathrm{C}$ in a $20 \mathrm{~cm}$ deep layer over a semi-isolated area of $0.5 \mathrm{~m}^{2}$; Figure 1). As the power source, a landline is most convenient, but a power generator, a solar power system or their combination may also be suitable for supplying heaters (ca. 100 heated terrestrial shelters or 2 submersible heaters $/ \mathrm{kW}$ ). The requirements these devices have to meet are the ability to heat up their immediate environment and amphibians therein to temperatures between 28 and $30^{\circ} \mathrm{C}$, to be portable and usable also in remote areas, to have relatively low power needs, to be cost-effective, be easy and safe to run also by non-academic personnel, and, importantly, to be attractive to amphibians. Solutions for several technical issues will have to be found, including the prevention of dehydration of amphibians using terrestrial warm spots, keeping individuals away from hot surfaces of heaters while still allowing efficient heat uptake, keeping predators away from amphibians aggregating on warm spots, or constructing funnel-trap-like one-way entrances for species or life-stages that would not use the provided warm spots for long enough voluntarily, but would endure these temperatures without damage. Finally, different climates and habitat types may require or allow for the use of different appliances. Consequently, the theoretical and technical expertise of electro technicians and energy engineers is likely to prove helpful during development and optimization, but none of these technical difficulties appear unsolvable.

\section{KNOWLEDGE GAPS THAT NEED TO BE FILLED}

Intensive research over the last two decades delivered detailed insights into several aspects of the biology of $B d$ and its interaction with amphibian hosts, but there have remained several important knowledge gaps that would first need to be filled before localized heating can be applied in situ routinely. One field where we lack sufficiently detailed information regards the combination of treatment duration and the temperature necessary to lower infection loads or clear $B d$ completely (for basic characteristics of the thermal ecology of $B d$ and of its interaction with amphibian hosts see Table 1). For the treatment of captive populations, where elevated temperatures can be provided for long periods without difficulty and immediate surveillance is possible, it may be sufficient to evaluate a combination of temperature and exposure timewhich experimentation reveals will clear $B d$ from a treated population-then apply that preventively or in case infection is suspected. However, for the in situ application of localized heating, where the energy available for heating is likely limited and the direct observation of treated individuals will often not be possible, we need to know rather exactly the combinations of minimum treatment temperatures and exposure durations that effectively lower infection loads of $B d$, or, preferably, lead to its complete clearance. In parallel, behavior of amphibians at various life-stages in relation to the use of warm spots will have to be studied to assess if individuals would voluntarily use warm areas for long enough (e.g., Sauer et al., 2018), or if repeated but short stays in warm spots may sufficiently lower $B d$ burdens 
(Greenspan et al., 2017a). This is necessary for deciding if heated areas can be designed so that animals can come and go at their will, or if they have to have funnel-trap-like one-way entrances to keep animals inside for long enough. In the latter scenario, conservation officers or scientists would need to manage the process, but this would create the opportunity to mark treated animals and follow up on their future, thereby obtaining reliable estimates on the efficiency of the applied in situ treatment.

Temperatures that are effective against $B d$ are relatively low, so that treatment of amphibians with elevated temperatures is considered a safe approach, and has been used in captive populations. Nonetheless, knowing the basics of the thermal ecology of the species to be treated is important because exposure to temperatures around $30^{\circ} \mathrm{C}$ during the entire larval period can already lower survival and growth rate of tadpoles and metamorphs of some species (Harkey and Semlitsch, 1988; Bellakhal et al., 2014; Goldstein et al., 2017). This knowledge can, however, be obtained by applying simple tests of heat tolerance (e.g., assessment of $\mathrm{CT}_{\max }$ by observing the temperature at which muscular coordination becomes disorganized; Hutchison, 1961; Huang et al., 2006; McCann et al., 2014; Greenspan et al., 2017b). Elevated temperatures may nonetheless also cause sublethal damage in treated individuals, which have remained largely ignored so far. High temperatures experienced during gametogenesis and gamete maturation have been proposed to impair gamete quality in adult amphibians (Woodhams et al., 2012), but we know of no report documenting such an effect at temperatures around $30^{\circ} \mathrm{C}$. Even if remaining below $\mathrm{CT}_{\max }$, environmental temperatures maintained at around $28-32^{\circ} \mathrm{C}$ for several weeks or during the entire larval period can lead to lowered growth and development rates (Angilletta and Dunham, 2003; Bellakhal et al., 2014; Carreira et al., 2016; Goldstein et al., 2017; Phuge, 2017), potentially depressing fitness of treated individuals (Smith, 1987; Semlitsch et al., 1988; Berven, 1990; Altwegg and Reyer, 2003; Schmidt et al., 2012). Also, even brief exposure to $30^{\circ} \mathrm{C}$ can increase stress hormone levels in adult frogs (Juráni et al., 1973; Narayan and Hero, 2014). However, within pessimal temperature limits, growth rate and overall physiological performance is positively related to temperature in ectotherms (Angilletta and Dunham, 2003; Carreira et al., 2016), and exposure to mildly elevated temperatures applied for a few days only is unlikely to lead to intolerable decreases in fitness even in species with a relatively low $\mathrm{CT}_{\max }$. Whether temporally limited exposure to mildly elevated temperatures can have significant negative fitness-effects remains to be assessed.

Elevated temperatures experienced during the sensitive period of larval development can lead to sex reversal in amphibians and only a handful of studies have so far investigated this phenomenon in amphibians (Chardard et al., 2004; Eggert, 2004; Nakamura, 2009). These studies report sex reversal to rarely occur with an effectiveness of $100 \%$ and only if environmental temperatures exceeding $28-32^{\circ} \mathrm{C}$ are maintained for weeks (Hsü et al., 1971; Dournon et al., 1984, 1990; Wallace et al., 1999; Wallace and Wallace, 2000; Chardard et al., 2004; Sakata et al., 2005; Phuge, 2017). Also, sex-reversed individuals may be infertile in some cases but fertile in others (Dournon et al., 1984; Wallace et al., 1999) and the sex-biasing effect may depend strongly on the timing of exposure to elevated temperatures
[Muto, 1961 reviewed in Chardard et al. (2004), Wallace et al. (1999) and Sakata et al. (2005)]. Further, temporal variation in temperature may disrupt the sex-reversing effect of heating (Neuwald and Valenzuela, 2011), while the $B d$-clearing effect may be upheld (Woodhams et al., 2003; Stevenson et al., 2014; Greenspan et al., 2017a). As sex reversal in amphibians (generally masculinization) is likely caused by lowered estrogen synthesis paralleled by elevated androgen and testosterone synthesis (Nakamura, 2009; Kitano et al., 2012), sex reversal could also be avoided by treating individuals with estrogen during heating, as shown in medaka (Kitano et al., 2012). However, the scarcity of reports makes it difficult to draw general conclusions (Chardard et al., 2004). Hence, for a safe application of elevated temperatures, it has to be determined if the temperature necessary to lower $B d$-burden in infected animals may affect life history traits negatively, lead to lowered fertilization success, to compromised offspring viability, or to high rates of sex reversal. It should also be assessed whether these malign effects may be prevented by allowing temporary fluctuations in body temperature of treated animals, by hormonal balancing or by careful selection of the timing of thermal treatment outside the sensitive developmental window.

The immune function of amphibians and the antibacterial and antifungal activity of their skin microbiome are generally assumed to be highest around $28-30^{\circ} \mathrm{C}$ (Raffel et al., 2006; Rollins-Smith et al., 2011; Paull et al., 2012; Daskin et al., 2014), while optimal temperatures may depend both on the species of amphibians and skin bacteria. However, elevated temperatures may also promote the replication of microparasites, such as Ranaviruses ((Echaubard et al., 2014; Price et al., 2019); but also see Rojas et al., 2005; Allender et al., 2013) or the growth, reproduction and infection intensity of macroparasites (Mouritsen, 2002; Thieltges and Rick, 2006; Studer et al., 2010; Tinsley et al., 2011; but also see Kluger, 1992; Lafferty, 2009). Relevant tests investigating whether exposure to elevated temperatures - as would be the case at warm spots-enhance the susceptibility of individuals to pathogens and parasites are scarce and contradictory (e.g., Rojas et al., 2005; Allender et al., 2013; Cohen et al., 2017; Price et al., 2019), and do not yet allow general conclusions. Studies on the effects of elevated temperature on disease progression in individuals co-infected with $B d$ and additional pathogens (especially thermophilic Ranaviruses) and parasites are lacking completely, and would be needed urgently. Also, the risk of infection can be positively related to density (Briggs et al., 2010), so that by using warm spots that are attractive to amphibians, individuals may suffer an elevated risk of contracting the disease at the resulting aggregations. However, it appears that disease transmission rates will likely be lowered in heated microhabitats (Blooi et al., 2015). Nonetheless, the net outcome of elevated temperature and high density as resulting from localized heating remains to be investigated.

\section{BENEFITS AND LIMITATIONS}

There are multiple benefits of using localized heating in situ against chytridiomycosis. It will presumably be effective also under natural conditions and is likely to pose no danger to amphibians because temperatures can be set with a wide enough 
safety margin (Sunday et al., 2014b). Also, localized heating will cause practically no collateral damage to the environment because it operates by only slightly elevating environmental temperatures in small spatial fractions of the habitat while leaving the microbiome, flora and fauna of the surrounding environment practically unaffected. Most importantly, however, as opposed to the ex situ approach, in case of localized heating applied in situ, individuals will come into contact with the pathogen and will be cured, often repeatedly, so that they may become immunized (Ramsey et al., 2010; McMahon et al., 2014; but also see Tobler and Schmidt, 2010; Hudson et al., 2016). Populations treated in situ may adapt to $B d$-presence via altered life history traits (Palomar et al., 2016), by the spread of certain MHC class II alleles (Savage and Zamudio, 2011, 2016; Bataille et al., 2015), or by producing more potent skin secretions (Voyles et al., 2018), providing effective defenses against lethal chytridiomycosis. Consequently, via these mechanisms and by preserving enough genetic variation and maintaining infected populations for a sufficiently long time period for microevolutionary changes to occur, in situ mitigation using localized heating may often allow for effective adaptation to $B d$ presence, making long-term mitigation interventions obsolete. Based on preliminary studies we estimate that the re-usable equipment (including 25 heated refugia, 5 immersible heaters and a power generator) necessary to provide enough warm spots for treating amphibians in and around a small pond of 1 ha will cost ca. 4,000 e. Consumables (mainly petrol for running the power generator) for one season will amount to another $4,000 e$, but this cost may be significantly lowered if electricity is available. Finally, transportation and personnel costs have to be added. The relatively low total costs of buying and running the equipment and a good transportability will allow for its application basically anywhere.

Nonetheless, there are also limitations to the application of localized heating. Species whose $\mathrm{CT}_{\max }$ is similar to that of $B d$ may avoid locations of high temperatures and will not profit from this mitigation approach (Nowakowski et al., 2016). Individuals of other species exhibiting a high enough $\mathrm{CT}_{\max }$, but a preferred body temperature that is lower than the upper bound of the optimal temperature range of $B d$, would also not spend enough time voluntarily at areas with elevated temperatures. Funneltrap-like, one-way entrances of heating appliances, coupled with attentive monitoring by personnel, may provide effective solutions. In very cold habitats, where the temperature stays below what is optimal for $B d$ (i.e., below ca. $12^{\circ} \mathrm{C}$; Piotrowski et al., 2004; Stevenson et al., 2013), heating may be impractical because of a high energy demand and because heaters may be unable to create high enough temperatures homogeneously within appliances, thereby increasing the reproductive rate and pathogenicity of the fungus locally (Pounds et al., 2006; Bosch et al., 2007). If environmental temperatures are high enough (higher than ca. $12^{\circ} \mathrm{C}$ ), both heated terrestrial shelters and submersible heaters can provide homogeneous warmth within appliances. However, the heat dissipating from them is not measurable $1 \mathrm{~cm}$ away from their walls, leading to essentially no temperature gradient around appliances. This has, however, the consequence that in cold habitats the heated areas may differ too much from the surroundings, so that they may be avoided by cold-habituated amphibians. Importantly, elevated temperatures may enhance replication rates and the spread of Ranaviruses, a group of globally emerging pathogens causing epidemics and mass-mortalities in fishes, amphibians and reptiles (Brunner et al., 2015; Duffus et al., 2015). Although results of the few existing studies are contradictory (Rojas et al., 2005; Allender et al., 2013; Echaubard et al., 2014; Price et al., 2019), a pre-screening for the presence of Ranaviruses is necessary before the application of localized heating, and in populations co-existing with a Ranavirus the application of localized heating can currently not be recommended. Finally, financing the necessary appliances, their transport to the target locations and the personnel running the equipment will be possible in many replicates, but an en masse employment of the proposed method will still remain limited by costs and logistics.

Eradicating $B d$ from entire geographic regions using localized heating, or, indeed, any mitigation method will often not be possible (Garner et al., 2016). It may, however, be suitable for the preservation of the most valuable populations. Also, it is an encouraging conclusion of previous studies that we do not have to eliminate $B d$ to prevent mass mortalities and extinctions due to chytridiomycosis (Briggs et al., 2010; Tobler et al., 2012; Schmeller et al., 2014; Hudson et al., 2016). For example, Vredenburg et al. (2010) observed in three North-American frog metapopulations that mass mortality only commenced once infection intensities passed a threshold. Experimental laboratorybased studies confirm that many amphibians do not show clinical signs and mortalities as long as infection intensities remain low (e.g., Carey et al., 2006; Cheng et al., 2011). Also, amphibian populations where the local climate allows individuals to elevate their body temperatures at least temporarily above the $\mathrm{CT}_{\max }$ of $B d$, and can thereby lower infection intensities, have been shown to maintain their population sizes even at high Bd prevalence (Riley et al., 2013; Rowley and Alford, 2013). Consequently, suppressing infection intensities and thereby ensuring the survival of amphibian populations in the presence of $B d$ may represent an effective, and usually the only viable in situ mitigation strategy (Garner et al., 2016).

Besides fighting $B d$, localized heating may also be applied against other emerging infectious diseases caused by agents whose $\mathrm{CT}_{\max }$ is lower than that of their hosts. For example, Batrachochytrium salamandrivorans ( $B s a l)$, a sister species of $B d$ that causes disease in urodelan amphibians (Martel et al., 2014) and has recently led to severe population declines in European newts and salamanders (Spitzen-van der Sluijs et al., 2013, 2016; Stegen et al., 2017), grows best at temperatures between 10 and $15^{\circ} \mathrm{C}$ and its $\mathrm{CT}_{\max }$ is around $25-26^{\circ} \mathrm{C}$ (Martel et al., 2013; Blooi et al., 2015; Laking et al., 2017; Beukema et al., 2018). Although these decisive temperatures are lower in Bsal than in $B d$, the preferred temperatures and $\mathrm{CT}_{\max }$ of urodeles are in general also lower than those of most anurans, so that localized heating may not work for clearing Bsal from many cold-preferring urodeles just by the effect of elevated temperatures. Nonetheless, it may very well be effective as a supportive mitigation action in many salamander and newt species, because even mildly elevated temperatures (i.e., $20^{\circ} \mathrm{C}$ ) may decisively limit the growth of $\mathrm{Bsal}$ (Martel et al., 2013; Blooi et al., 2015). Also, exogenous heat 
introduced into water bodies used by urodelans for reproduction accumulates via convection at the water-air interface, where Bsal cysts float out of reach for most aquatic predators (Stegen et al., 2017). If Bsal cysts exhibit similarly low $\mathrm{CT}_{\max }$ as non-encysted cells, the application of localized heating may, as a beneficial sideeffect, also critically reduce densities of these otherwise resistant and infective life-stages of Bsal.

\section{SUMMARY}

Widely deployable and effective measures of $B d$-mitigation are urgently needed for averting the ongoing biodiversity crisis caused by chytridiomycosis. After an epizootic caused by $B d$ lead to sharp declines in previously stable amphibian metapopulations, a slow recovery may occur in some species (Newell et al., 2013; Knapp et al., 2016; Scheele et al., 2017; Voyles et al., 2018), but many others will be extinct. Also, new $B d$ strains, other infections or invasive alien predators may arrive, anthropogenic pollution, or simply chance events may cause the weakened amphibian populations to disappear (Murray et al., 2009; Puschendorf et al., 2011). We suggest a method that could be used far more easily and more widely while causing less collateral damage than any method which has been suggested so far for in situ $B d$-mitigation. It is unlikely that one single method will solve the conservation problem posed by $B d$ (Garner et al., 2016), and research into other methods that have proven to be successful in captive populations and that are being tested and optimized for application in the field are urgently needed. Nonetheless, localized heating will likely prove to be a highly valuable approach, especially in the case of disease outbreaks and when the most threatened species or populations are to be saved. If mortality rates due to chytridiomycosis are suppressed by the application of localized heating, genetic variability may be retained in populations that selection can act upon: alleles promoting resistance or tolerance

\section{REFERENCES}

Allender, M. C., Mitchell, M. A., Torres, T., Sekowska, J., and Driskell, E. A. (2013). Pathogenicity of frog virus 3-like virus in red-eared slider turtles (Trachemys scripta elegans) at two environmental temperatures. J. Comp. Pathol. 149, 356-367. doi: 10.1016/j.jcpa.2013.01.007

Altwegg, R., and Reyer, H. U. (2003). Patterns of natural selection on size at metamorphosis in water frogs. Evolution 57, 872-882. doi: 10.1111/j.0014-3820.2003.tb00298.x

Andre, S. E., Parker, J., and Briggs, C. J. (2008). Effect of temperature on host response to Batrachochytrium dendrobatidis infection in the mountain yellow-legged frog (Rana muscosa). J. Wildlife Dis. 44, 716-720. doi: 10.7589/0090-3558-44.3.716

Angilletta, M. J. Jr., and Dunham, A. E. (2003). The temperature-size rule in ectotherms: simple evolutionary explanations may not be general. Am. Nat. 162, 332-342. doi: 10.1086/377187

Antwis, R. E., Preziosi, R. F., Harrison, X. A., and Garner, T. W. J. (2015). Amphibian symbiotic bacteria do not show a universal ability to inhibit growth of the global panzootic lineage of Batrachochytrium dendrobatidis. Appl. Environ. Microbiol. 81, 3706-3711. doi: 10.1128/AEM.00010-15

Bataille, A., Cashins, S. D., Grogan, L., Skerratt, L. F., Hunter, D., McFadden, M., et al. (2015). Susceptibility of amphibians to chytridiomycosis is to $B d$ may not disappear during severe genetic bottlenecks and may spread so that prolonged mitigation may become obsolete. We do not propose that by researching and applying localized heating it will become possible to eradicate $B d$ from entire regions or save all extant amphibian species from extinction due to chytridiomycosis, but suggest that this method has a good potential for significantly contributing to the preservation of hundreds of populations and dozens of species that are likely to go extinct unless we find and employ an effective mitigation strategy against this deadly disease.

\section{DATA AVAILABILITY}

No datasets were generated or analyzed for this study.

\section{AUTHOR CONTRIBUTIONS}

All authors listed have made a substantial, direct and intellectual contribution to the work, and approved it for publication.

\section{FUNDING}

AH was supported by the Lendület programme of the Hungarian Academy of Sciences (MTA, LP2012-24/2012), by the National Research, Development and Innovation Office (NKFIH) of Hungary (grant no. K-124375), a János Bolyai Scholarships of the MTA, and a Bolyai+ Scholarship of the New National Excellence Programme of the Ministry of Human Capacities, Hungary (ÚNKP, EMMI), DH by the Young Investigators Programme (FiKut) of the MTA.

\section{ACKNOWLEDGMENTS}

We thank Susan C. Walls and two reviewers for providing insightful and detailed comments on earlier versions of the paper.

associated with MHC class II conformation. Proc. R. Soc. B 282:20143127. doi: 10.1098/rspb.2014.3127

Bellakhal, M., Neveu, A., Fartouna-Bellakhal, M., Missaoui, H., and Aleya, L. (2014). Effects of temperature, density and food quality on larval growth and metamorphosis in the north African green frog Pelophylax saharicus. J. Therm. Biol. 45, 81-86. doi: 10.1016/j.jtherbio.2014.08.006

Berger, L., Speare, R., Daszak, P., Green, D. E., Cunningham, A. A., Goggin, C. L., et al. (1998). Chytridiomycosis causes amphibian mortality associated with population declines in the rain forests of Australia and Central America. Proc. Natl. Acad. Sci. U.S.A. 95, 9031-9036. doi: 10.1073/pnas.95. 15.9031

Berger, L., Speare, R., Hines, H., Marantelli, G., Hyatt, A. D., McDonald, K. R., et al. (2004). Effect of season and temperature on mortality in amphibians due to chytridiomycosis. Aust. Vet. J.. 82, 434-439. doi: 10.1111/j.1751-0813.2004.tb11137.x

Berger, L., Speare, R., Pessier, A., Voyles, J., and Skerratt, L. F. (2010). Treatment of chytridiomycosis requires urgent clinical trials. Dis. Aquat. Org. 92, 165-174. doi: 10.3354/dao02238

Berger, L., Speare, R., and Skerratt, L. (2005). Distribution of Batrachochytrium dendrobatidis and pathology in the skin of green tree frogs (Litoria caerulea) with severe chytridiomycosis. Dis. Aquat. Org. 68, 65-70. doi: $10.3354 /$ dao068065 
Berven, K. A. (1990). Factors affecting population fluctuations in larval and adult stages of the wood frog (Rana sylvatica). Ecology 71, 1599-1608. doi: $10.2307 / 1938295$

Beukema, W., Martel, A., Nguyen, T. T., Goka, K., Schmeller, D. S., Yuan, Z., et al. (2018). Environmental context and differences between native and invasive observed niches of Batrachochytrium salamandrivorans affect invasion risk assessments in the Western Palaearctic. Divers. Distrib. 24, 1788-1801. doi: 10.1111/ddi.12795

Blaustein, A. R., Romansic, J. M., Scheessele, E. A., Han, B. A., Pessier, A. P., and Longcore, J. E. (2005). Interspecific variation in susceptibility of frog tadpoles to the pathogenic fungus Batrachochytrium dendrobatidis. Conserv. Biol. 19, 1460-1468. doi: 10.1111/j.1523-1739.2005.00195.x

Blooi, M., Martel, A., Haesebrouck, F., Vercammen, F., Bonte, D., and Pasmans, F. (2015). Treatment of urodelans based on temperature dependent infection dynamics of Batrachochytrium salamandrivorans. Sci. Rep. 5:8037. doi: $10.1038 /$ srep 08037

Bosch, J., Carrascal, J. M., Durán, L., Walker, S., and Fisher, M. C. (2007). Climate change and outbreaks of amphibian chytridiomycosis in a montane area of Central Spain; is there a link? Proc. R. Soc. B 274, 253-260. doi: 10.1098/rspb.2006.3713

Bosch, J., Sanchez-Tomé, E., Fernández-Loras, A., Oliver, J. A., Fisher, M. C., and Garner, T. W. J. (2015). Successful elimination of a lethal wildlife infectious disease in nature. Biol. Lett. 11:20150874. doi: 10.1098/rsbl.2015.0874

Bradley, G. A., Rosen, P. C., Sredl, M. J., Jones, T. R., and Longcore, J. E. (2002). Chytridiomycosis in native Arizona frogs. J. Wildlife Dis. 38, 206-212. doi: 10.7589/0090-3558-38.1.206

Briggs, C. J., Knapp, R. A., and Vredenburg, V. T. (2010). Enzootic and epizootic dynamics of the chytrid fungal pathogen of amphibians. Proc. Natl. Acad. Sci. U.S.A. 107, 9695-9700. doi: 10.1073/pnas.0912886107

Brunner, J. L., Storfer, A., Gray, M. J., and Hoverman, J. T. (2015). "Ranavirus ecology and evolution: from epidemiology to extinction," in Ranaviruses, eds M. J. Gray and V. G. Chinchar (Heidelberg: Springer), 71-104. doi: 10.1007/978-3-319-13755-1_4

Buck, J. C., Truong, L., and Blaustein, A. R. (2011). Predation by zooplankton on Batrachochytrium dendrobatidis: biological control of the deadly amphibian chytrid fungus? Biodivers. Conserv. 20, 3549-3553. doi: 10.1007/s10531-011-0147-4

Bustamante, H. M., Livo, L. J., and Carey, C. (2010). Effects of temperature and hydric environment on survival of the Panamanian Golden Frog infected with a pathogenic chytrid fungus. Integr. Zool. 5, 143-153. doi: 10.1111/j.1749-4877.2010.00197.x

Campbell, C. R., Voyles, J., Cook, D. I., and Dinudom, A. (2012). Frog skin epithelium: electrolyte transport and chytridiomycosis. Int. J. Biochem. Cell Biol. 44, 431-434. doi: 10.1016/j.biocel.2011.12.002

Carey, C., Bruzgul, J. E., Livo, L. J., Walling, M. L., Kuehl, K. A., Dixon, B. F., et al. (2006). Experimental exposures of boreal toads (Bufo boreas) to a pathogenic chytrid fungus (Batrachochytrium dendrobatidis). Ecohealth 3, 5-21. doi: 10.1007/s10393-005-0006-4

Carreira, B. M., Segurado, P., Orizaola, G., Gonçalves, N., Pinto, V., Laurila, A., et al. (2016). Warm vegetarians? Heat waves and diet shifts in tadpoles. Ecology 97, 2964-2974. doi: 10.1002/ecy.1541

Cashins, S. D., Grogan, L. F., McFadden, M., Hunter, D., Harlow, P. S., Berger, L., et al. (2013). Prior infection does not improve survival against the amphibian disease Chytridiomycosis. PLoS ONE 8:e56747. doi: 10.1371/journal.pone.0056747

Chardard, D., Penrad-Mobayed, M., Chesnel, A., Pieau, C., and Dournon, C. (2004). "Thermal sex reversals in amphibians," in Temperature-dependent Sex Determination in Vertebrates, eds N. Valenzuela and V. Lance (Washington, DC: Smithsonian Books), 59-67.

Chatfield, M., and Richards-Zawacki, C. (2011). Elevated temperature as a treatment for Batrachochytrium dendrobatidis infection in captive frogs. Dis. Aquat. Org. 94, 235-238. doi: 10.3354/dao02337

Cheng, T. L., Rovito, S. M., Wake, D. B., and Vredenburg, V. T. (2011). Coincident mass extirpation of neotropical amphibians with the emergence of the infectious fungal pathogen Batrachochytrium dendrobatidis. Proc. Natl. Acad. Sci. U.S.A. 108, 9502-9507. doi: 10.1073/pnas.1105538108

Clare, F. C., Halder, J. B., Daniel, O., Bielby, J., Semenov, M. A., Jombart, T., et al. (2016). Climate forcing of an emerging pathogenic fungus across a montane multi-host community. Phil. Trans. R. Soc. B 371:20150454. doi: $10.1098 /$ rstb.2015.0454

Cohen, J. M., Civitello, D. J., Venesky, M. D., McMahon, T. A., and Rohr, J. R. (2018). An interaction between climate change and infectious disease drove widespread amphibian declines. Glob. Change Biol. 25, 927-937. doi: $10.1111 / \mathrm{gcb} .14489$

Cohen, J. M., McMahon, T. A., Ramsay, C., Roznik, E. A., Sauer, E. L., Bessler, S., et al. (2019). Impacts of thermal mismatches on chytrid fungus Batrachochytrium dendrobatidis prevalence are moderated by life stage, body size, elevation and latitude. Ecol. Lett. 22, 817-825. doi: 10.1111/ele.13239

Cohen, J. M., Venesky, M. D., Sauer, E. L., Civitello, D. J., McMahon, T. A., Roznik, E. A., et al. (2017). The thermal mismatch hypothesis explains host susceptibility to an emerging infectious disease. Ecol. Lett. 20, 184-193. doi: $10.1111 /$ ele. 12720

Conlon, M. J., Iwamuro, S., and King, J. D. (2009). Dermal cytolytic peptides and the system of innate immunity in anurans. Ann. N. Y. Acad. Sci. 1163, 75-82. doi: 10.1111/j.1749-6632.2008.03618.x

Daskin, J. H., Alford, R. A., and Puschendorf, R. (2011). Shortterm exposure to warm microhabitats could explain amphibian persistence with Batrachochytrium dendrobatidis. PLOS ONE 6:e26215. doi: 10.1371/journal.pone.0026215

Daskin, J. H., Bell, S. C., Schwarzkopf, L., and Alford, R. A. (2014). Cool temperatures reduce antifungal activity of symbiotic bacteria of threatened amphibians-implications for disease management and patterns of decline. PLOS ONE 9:e100378. doi: 10.1371/journal.pone.0100378

Daszak, P., Cunningham, A. A., and Hyatt, A. D. (2000). Emerging infectious diseases of wildlife-threats to biodiversity and human health. Science 287, 443-449. doi: 10.1126/science.287.5452.443

Dournon, C., Guillet, F., Boucher, D., and Lacroix, J. C. (1984). Cytogenetic and genetic evidence of male sexual inversion by heat treatment in the newt Pleurodeles poireti. Chromosoma 90, 261-264. doi: 10.1007/BF00287033

Dournon, C., Houillon, C. H., and Pieau, C. (1990). Temperature sex-reversal in amphibians and reptiles. Int. J. Dev. Biol. 34, 81-92.

Duffus, A. L. J., Waltzek, T. B., Stöhr, A. C., Allender, M. C., Gotesman, M., Whittington, R. J., et al. (2015). "Distribution and host range of Ranaviruses," in Ranaviruses, eds M. J. Gray and V. G. Chinchar (Springer), 71-104. doi: 10.1007/978-3-319-13755-1_2

Dupré, R. K., and Petranka, J. W. (1985). Ontogeny of temperature selection in larval amphibians. Copeia 1985, 462-467. doi: 10.2307/1444859

Echaubard, P., Leduc, J., Pauli, B., Chinchar, V. G., Robert, J., and Lesbarrères, D. (2014). Environmental dependency of amphibian-ranavirus genotypic interactions: evolutionary perspectives on infectious diseases. Evol. Appl. 7 , 723-733. doi: 10.1111/eva.12169

Eggert, C. (2004). Sex determination: the amphibian models. Reprod. Nutr. Dev. 44, 539-549. doi: 10.1051/rnd:2004062

Farrer, R. A., Weinert, L. A., Bielby, J., Balloux, F., Clare, F., Bosch, J., et al. (2011). Multiple emergences of genetically diverse amphibian-infecting chytrids include a globalized hypervirulent recombinant lineage. Proc. Natl. Acad. Sci. U.S.A. 108, 18732-18736. doi: 10.1073/pnas.1111915108

Fernández-Beaskoetxea, S., Carrascal, L. M., Fernández-Loras, A., Fisher, M. C., and Bosch, J. (2015). Short term minimum water temperatures determine levels of infection by the amphibian chytrid fungus in Alytes obstetricans tadpoles. PLoS ONE 10:e0120237. doi: 10.1371/journal.pone.0120237

Fisher, M. C., Garner, T. W. J., and Walker, S. F. (2009). Global emergence of Batrachochytrium dendrobatidis and amphibian chytridiomycosis in space, time, and host. Annu. Rev. Microbiol. 63, 291-310. doi: $10.1146 /$ annurev.micro.091208.073435

Fontenot, C. L. Jr., and Lutterschmidt, W. I. (2011). Thermal selection and temperature preference of the aquatic salamander, Amphiuma tridactylum. Herpetol. Conserv. Biol. 6, 395-399.

Forrest, M. J., and Schlaepfer, M. A. (2011). Nothing a hot bath won't cure: infection rates of amphibian chytrid fungus correlate negatively with water temperature under natural field settings. PLOS ONE 6:e28444. doi: 10.1371/journal.pone.0028444

Gabor, C. R., Fisher, M. C., and Bosch, J. (2015). Elevated corticosterone levels and changes in amphibian behavior are associated with Batrachochytrium dendrobatidis (Bd) infection and Bd lineage. PLOS ONE 10:e0122685. doi: 10.1371 /journal.pone. 0122685 
Garmyn, A., Van Rooij, P., Pasmans, F., Hellebuyck, T., Van Den Broeck, W., Haesebrouck, F., et al. (2012). Waterfowl: potential environmental reservoirs of the chytrid fungus Batrachochytrium dendrobatidis. PLoS ONE 7:e35038. doi: 10.1371/journal.pone.0035038

Garner, T. W. J., Perkins, M. W., Govindarajulu, P., Seglie, D., Walker, S., and Cunningham AA Fisher, M. C. (2006). Global distribution of Batrachochytrium dendrobatidis infection in introduced populations of the North American bullfrog, Rana catesbeiana. Biol. Lett. 2, 455-459. doi: 10.1098/rsbl.2006.0494

Garner, T. W. J., Schmidt, B. R., Martel, A., Pasmans, F., Muths, E., Cunningham, A. A., et al. (2016). Mitigating amphibian chytridiomycosis in nature. Philos. Trans. R. Soc. B 371:20160207. doi: 10.1098/rstb.2016.0207

Garner, T. W. J., Walker, S., Bosch, J., Leech, S., Rowcliffe, M., Cunningham, A. A., et al. (2009). Life history tradeoffs influence mortality associated with the amphibian pathogen Batrachochytrium dendrobatidis. Oikos 118, 783-791. doi: 10.1111/j.1600-0706.2008.17202.x

Geiger, C. C., Bregnard, C., Maluenda, E., Voordouw, M. J., and Schmidt, B. R. (2017). Antifungal treatment of wild amphibian populations caused a transient reduction in the prevalence of the fungal pathogen, Batrachochytrium dendrobatidis. Sci. Rep. 7:5956. doi: 10.1038/s41598-017-05798-9

Geiger, C. C., Küpfer, E., Schär, S., Wolf, S., and Schmidt, B. R. (2011). Elevated temperature clears chytrid fungus infections from tadpoles of the midwife toad, Alytes obstetricans. Amphibia-Reptilia 32, 276-280. doi: 10.1163/017353711X556970

Goldstein, J. A., von Seckendorr Hoff, K., and Hillyard, S. D. (2017). The effect of temperature on development and behaviour of relict leopard frog tadpoles. Conserv. Physiol. 5, 1-8. doi: 10.1093/conphys/cow075

Greenspan, S. E., Bower, D. S., Roznik, E. A., Pike, D. A., Marantelli, G., Alford, R. A., et al. (2017b). Infection increases vulnerability to climate change via effects on host thermal tolerance. Sci. Rep. 7:9349. doi: 10.1038/s41598-017-09950-3

Greenspan, S. E., Bower, D. S., Webb, R. J., Roznik, E. A., Stevenson, L. A., Berger, L., et al. (2017a). Realistic heat pulses protect frogs from disease under simulated rainforest frog thermal regimes. Funct. Ecol. 31, 2274-2286. doi: 10.1111/1365-2435.12944

Gutiérrez-Pesquera, L. M., Tejedo, M., Olalla-Tárraga, M. Á., Duarte, H., Nicieza, A., and Solé, M. (2016). Testing the climate variability hypothesis in thermal tolerance limits of tropical and temperate tadpoles. J. Biogeogr. 43, 1166-1178. doi: $10.1111 /$ jbi. 12700

Han, B. A., Bradley, P. W., and Blaustein, A. R. (2008). Ancient behaviors of larval amphibians in response to an emerging fungal pathogen, Batrachochytrium dendrobatidis. Behav. Ecol. Sociobiol. 63, 241-250. doi: 10.1007/s00265-008-0655-8

Hanlon, S. M., Lynch, K. J., Kerby, J., and Parris, M. J. (2015). Batrachochytrium dendrobatidis exposure effects on foraging efficiencies and body size in anuran tadpoles. Dis. Aquat. Org. 112, 237-242. doi: 10.3354/dao02810

Harkey, G. A., and Semlitsch, R. D. (1988). Effects of temperature on growth, development, and color polymorphism in the Ornate chorus frog Pseudacris ornata. Copeia 4, 1001-1007. doi: 10.2307/1445724

Harris, R. N., Brucker, R. M., Walke, J. B., Becker, M. H., Schwantes, C. R., Flaherty, D. C., et al. (2009b). Skin microbes on frogs prevent morbidity and mortality caused by a lethal skin fungus. ISME J. 3, 818-824. doi: 10.1038/ismej.2009.27

Harris, R. N., James, T. Y., Lauer, A., Simon, M. A., and Patel, A. (2006). Amphibian pathogen Batrachochytrium dendrobatidis is inhibited by the cutaneous bacteria of amphibian species. EcoHealth 3, 53-56. doi: 10.1007/s10393-005-0009-1

Harris, R. N., Lauer, A., Simon, M. A., Banning, J. L., and Alford, R. A. (2009a). Addition of antifungal skin bacteria to salamanders ameliorates the effects of chytridiomycosis. Dis. Aquat. Org. 83, 11-16. doi: 10.3354/dao02004

Heard, G. W., Scroggie, M. P., Clemann, N., and Ramsey, D. S. L. (2014). Wetland characteristics influence disease risk for a threatened amphibian. Ecol. Appl.24, 650-662. doi: 10.1890/13-0389.1

Heath, A. G. (1975). Behavioral thermoregulation in high altitude tiger salamanders, Ambystoma tigrinum. Herpetologica 31, 84-93.

Houlahan, J. E., Findlay, C. S., Schmidt, B. R., Meyer, A. H., and Kuzmin, S. L. (2000). Quantitative evidence for global amphibian population declines. Nature 404, 752-755. doi: 10.1038/35008052

Hsü, C.-Y., Yü, N.-W., and Liang, H.-M. (1971). Induction of sex reversal in female tadpoles of Rana catesbeiana by temperature treatment. Endocrinol. Jpn. 18, 243-251. doi: 10.1507/endocrj1954.18.243
Huang, S.-P., Hsu, Y., and Tu, M.-C. (2006). Thermal tolerance and altitudinal distribution of two Sphenomorphus lizards in Taiwan. J. Therm. Biol. 31, 378-385. doi: 10.1016/j.jtherbio.2005.11.032

Hudson, M. A., Young, R. P., Lopez, Y., Martin, L., Fenton, C., McCrea, R., et al. (2016). In-situ itraconazole treatment improves survival rate during an amphibian chytridiomycosis epidemic. Biol. Conserv. 195, 37-45. doi: 10.1016/j.biocon.2015.12.041

Hutchison, V. H. (1961). Critical thermal maxima in salamanders. Physiol. Zool. 34, 92-125. doi: 10.1086/physzool.34.2.30152688

Hutchison, V. H., and Hill, L. G. (1976). Thermal selection in the hellbender, Cryptobranchus alleganiensis, and the mudpuppy, Necturus maculosus. Herpetologica 32, 327-331.

IUCN (2016). The IUCN Red List of Threatened Species. Version 2016-2. Available online at: http://www.iucnredlist.org (accessed February 8, 2017).

James, T. Y., Toledo, L. F., Rödder, D., da Silva Leite, D., Belasen, A. M., Betancourt-Román, C. M., et al. (2015). Disentangling host, pathogen, and environmental determinants of a recently emerged wildlife disease: lessons from the first 15 years of amphibian chytridiomycosis research. Ecol. Evol. 5 , 4079-4097. doi: 10.1002/ece3.1672

Jenkinson, T. S., Betancourt Román, C. M., Lambertini, C., Valencia-Aguilar, A., Rodriguez, D., Nunes-de-Almeida, C. H., et al. (2016). Amphibian-killing chytrid in Brazil comprises both locally endemic and globally expanding populations. Mol. Ecol. 25, 2978-2996. doi: 10.1111/mec.13599

Johnson, M. L., Berger, L., Philips, L., and Speare, R. (2003). Fungicidal effects of chemical disinfectants, UV light, desiccation and heat on the amphibian chytrid Batrachochytrium dendrobatidis. Dis. Aquat. Org. 57, 255-260. doi: 10.3354/dao057255

Juráni, M., Murgas, K., Mikulaj, L., and Babusíková, F. (1973). Effect of stress and environmental temperature on adrenal function in Rana esculenta. J. Endocrinol. 57, 385-391. doi: 10.1677/joe.0.0570385

Karavlan, S. A., and Venesky, M. D. (2016). Thermoregulatory behavior of Anaxyrus americanus in response to infection with Batrachochytrium dendrobatidis. Copeia 104, 746-751. doi: 10.1643/CH-15-299

Kitano, T., Hayashi, Y., Shiraishi, E., and Kamei, Y. (2012). Estrogen rescues masculinization of genetically female medaka by exposure to cortisol or high temperature. Mol. Reprod. Dev. 79, 719-726. doi: 10.1002/mrd.22080

Kluger, M. J. (1977). Fever in the frog Hyla cinerea. J. Therm. Biol. 2, 79-81. doi: 10.1016/0306-4565(77)90042-0

Kluger, M. J. (1992). Fever revisited. Pediatrics 90, 846-850.

Knapp, R. A., Fellers, G. M., Kleeman, P. M., Miller, D. A. W., Vredenburg, V. T., Rosenblum, E. B., et al. (2016). Large-scale recovery of an endangered amphibian despite ongoing exposure to multiple stressors. Proc. Natl. Acad. Sci. U.S.A. 113, 11889-11894. doi: 10.1073/pnas.16009 83113

Kriger, K. M., Pereoglou, F., and Hero, J. M. (2007). Latitudinal variation in the prevalence and intensity of chytrid (Batrachochytrium dendrobatidis) infection in Eastern Australia. Conserv. Biol. 21, 1280-1290. doi: 10.1111/j.1523-1739.2007.00777.x

La Marca, E., Lips, K. R., Lötters, S., Puschendorf, R., Ibáñez, R., Rueda-Almonacid, J. V., et al. (2005). Catastrophic population declines and extinctions in neotropical Harlequin Frogs (Bufonidae: Atelopus). Biotropica 37, 190-201. doi: $10.1111 / j .1744-7429.2005 .00026 . x$

Lafferty, K. D. (2009). The ecology of climate change and infectious diseases. Ecology 90, 888-900. doi: 10.1890/08-0079.1

Laking, A. E., Ngo, H. N., Pasmans, F., Martel, A., and Nguyen, T. T. (2017). Batrachochytrium salamandrivorans is the predominant chytrid fungus in Vietnamese salamanders. Sci. Rep. 7:44443 doi: 10.1038/srep44443

Lam, B. A., Walke, J. B., Vredenburg, V. T., and Harris, R. N. (2010). Proportion of individuals with anti-Batrachochytrium dendrobatidis skin bacteria is associated with population persistence in the frog Rana muscosa. Biol. Conserv. 143, 529-531. doi: 10.1016/j.biocon.2009.11.015

Lam, B. A., Walton, D. B., and Harris, R. N. (2011). Motile zoospores of Batrachochytrium dendrobatidis move away from antifungal metabolites produced by amphibian skin bacteria. EcoHealth 8, 36-45. doi: 10.1007/s10393-011-0689-7

Lefcort, H., and Blaustein, A. R. (1995). Disease, predator avoidance, and vulnerability to predation in tadpoles. Oikos 74, 469-474. doi: 10.2307/3545992 
Licht, P., and Brown, A. G. (1967). Behavioral thermoregulation and its role in the ecology of the red-bellied newt, Taricha rivularis. Ecology 48, 598-611. doi: $10.2307 / 1936504$

Lips, K. R. (2016). Overview of chytrid emergence and impacts on amphibians. Philos. Trans. R. Soc. B 371:20150465. doi: 10.1098/rstb.2015.0465

Lips, K. R., Brem, F., Brenes, R., Reeve, J. D., Alford, R. A., Voyles, J., et al. (2006). Emerging infectious disease and the loss of biodiversity in a Neotropical amphibian community. Proc. Natl. Acad. Sci. U.S.A. 103, 3165-3170. doi: 10.1073/pnas.0506889103

Lips, K. R., Diffendorfer, J., Mendelson, J. R. III, and Sears, M. W. (2008). Riding the wave: reconciling the roles of disease and climate change in amphibian declines. PLoS Biol. 6, 441-454. doi: 10.1371/journal.pbio.0060072

Longcore, J. E., Pessier, A. P., and Nichols, D. K. (1999). Batrachochytrium dendrobatidis gen. et sp. nov., a chytrid pathogenic to amphibians. Mycologia 91, 219-227. doi: 10.1080/00275514.1999.12061011

Martel, A., Blooi, M., Adriaensen, C., Van Rooij, P., Beukema, W., Fisher, M. C., et al. (2014). Recent introduction of a chytrid fungus endangers Western Palearctic salamanders. Science 346, 630-631. doi: 10.1126/science.1258268

Martel, A., Spitzen-van der Sluijs, A., Blooi, M., Bert, W., Ducatelle, R., Fisher, M. C., et al. (2013). Batrachochytrium salamandrivorans sp. nov. causes lethal chytridiomycosis in amphibians. Proc. Natl. Acad. Sci. U.S.A. 110, 15325-15329. doi: 10.1073/pnas.1307356110

McCann, S., Greenlees, M. J., Newell, D., and Shine, R. (2014). Rapid acclimation to cold allows the cane toad to invade montane areas within its Australian range. Funct. Ecol. 28, 1166-1174. doi: 10.1111/1365-2435.12255

McMahon, T. A., Brannelly, L. A., Chatfield, M. W. H., Johnson, P. T. J., Joseph, M. B., McKenzie, V. J., et al. (2013). Chytrid fungus Batrachochytrium dendrobatidis has nonamphibian hosts and releases chemicals that cause pathology in absence of infection. Proc. Natl. Acad. Sci. U.S.A. 110, 210-215. doi: 10.1073/pnas. 1200592110

McMahon, T. A., Sears, B. F., Venesky, M. D., Bessler, S. M., Brown, J. M., Deutsch, K., et al. (2014). Amphibians acquire resistance to live and dead fungus overcoming fungal immunosuppression. Nature 511, 224-227. doi: 10.1038/nature13491

Mouritsen, K. N. (2002). The Hydrobia ulvae - Maritrema subdolum association: influence of temperature, salinity, light, water pressure and secondary host exudates on cercarial emergence and longevity. J. Helminthol. 76, 341-347. doi: $10.1079 / \mathrm{JOH} 2002136$

Muletz, C. R., Myers, J. M., Domangue, R. J., Herrick, J. B., and Harris, R. N. (2012). Soil bioaugmentation with amphibian cutaneous bacteria protects amphibian hosts from infection by Batrachochytrium dendrobatidis. Biol. Conserv. 152, 119-126. doi: 10.1016/j.biocon.2012.03.022

Murphy, P. J., St.-Hilaire, S., and Corn, P. S. (2011). Temperature, hydric environment, and prior pathogen exposure alter the experimental severity of chytridiomycosis in boreal toads. Dis. Aquat. Org. 95, 31-42. doi: 10.3354/dao02336

Murray, K. A., Skerratt, L. F., Speare, R., and McCallum, H. (2009). Impact and dynamics of disease in species threatened by the amphibian chytrid fungus, Batrachochytrium dendrobatidis. Conserv. Biol. 23, 1242-1252. doi: 10.1111/j.1523-1739.2009.01211.x

Muths, E., Scherer, R. G., and Pilliod, D. S. (2011). Compensatory effects of recruitment and survival when amphibian populations are perturbed by disease. J. Appl. Ecol. 48, 873-879. doi: 10.1111/j.1365-2664.2011.02005.x

Muto, Y. (1961). The gonad of the toad, Bufo vulgaris formosus, cultured at high temperature. Bull. Aichi. Gakugei. Univ. 10, 97-109.

Nakamura, M. (2009). Sex determination in amphibians. Semin. Cell Dev. Biol. 20, 271-282. doi: 10.1016/j.semcdb.2008.10.003

Narayan, E. J., and Hero, J-M. (2014). Acute thermal stressor increases glucocorticoid response but minimizes testosterone and locomotor performance in the cane toad (Rhinella marina). PLoS ONE 9, 1-6. doi: 10.1371/journal.pone.0092090

Neuwald, J. L., and Valenzuela, N. (2011). The lesser known challenge of climate change: thermal variance and sex-reversal in vertebrates with temperature-dependent sex determination. PLoS ONE 6:e18117. doi: 10.1371/journal.pone.0018117

Newell, D. A., Goldingay, R. L., and Brooks, L. O. (2013). Population recovery following decline in an endangered stream-breeding frog
(Mixophyes fleayi) from subtropical Australia. PLoS ONE 8:e58559. doi: 10.1371/journal.pone.0058559

Nowakowski, A. J., Whitfield, S. M., Eskew, E. A., Thompson, M. E., Rose, J. P., Caraballo, B. L., et al. (2016). Infection risk decreases with increasing mismatch in host and pathogen environmental tolerances. Ecol. Lett. 19, 1051-1061. doi: 10.1111/ele.12641

O'Hanlon, S. J., Rieux, A., Farrer, R. A., Rosa, G. M., Waldman, B., Bataille, A., et al. (2018). Recent Asian origin of chytrid fungi causing global amphibian declines. Science 360, 621-627. doi: 10.1126/science.aar1965

Palomar, G., Bosch, J., and Cano, J. M. (2016). Heritability of Batrachochytrium dendrobatidis burden and its genetic correlation with development time in a population of Common toad (Bufo spinosus). Evolution 70, 2346-2356. doi: $10.1111 /$ evo.13029

Paull, S. H., Lafonte, B. E., and Johnson, P. T. J. (2012). Temperature-driven shifts in a host-parasite interaction drive nonlinear changes in disease risk. Glob. Change Biol. 18, 3558-3567. doi: 10.1111/gcb.12018

Pessier, A. P. (2008). Management of disease as a threat to amphibian conservation. Int. Zoo Yearb. 42, 30-39. doi: 10.1111/j.1748-1090.2008.00047.x

Phuge, S. K. (2017). High temperatures influence sexual development differentially in male and female tadpoles of the Indian skipper frog, Euphlyctis cyanophlyctis. J. Biosci. 42, 449-457. doi: 10.1007/s12038-017-9689-2

Piotrowski, J. S., Annis, S. L., and Longcore, J. E. (2004). Physiology of Batrachochytrium dendrobatidis, a chytrid pathogen of amphibians. Mycologia 96, 9-15. doi: 10.1080/15572536.2005.11832990

Pounds, J. A., Bustamante, M. R., Coloma, L. A., Consuegra, L. A., Fogden, M. P. L., Foster, P. N., et al. (2006). Widespread amphibian extinctions from epidemic disease driven by global warming. Nature 439, 143-144. doi: 10.1038/nature04246

Price, S. J., Leung, W. T. M., Owen, C., Sergeant, C., Cunningham, A. A., Balloux, F., et al. (2019). Temperature is a key driver of a wildlife epidemic and future warming will increase impacts. bioRxiv. doi: 10.1101/272369

Puschendorf, R., Hoskin, C. J., Cashins, S. D., McDonald, K., Skerratt, L. F., Vanderwal, J., et al. (2011). Environmental refuge from disease-driven amphibian extinction. Conserv. Biol. 25, 956-964. doi: 10.1111/j.1523-1739.2011.01728.x

Rachowicz, L. J., Hero, J. M., Alford, R. A., Taylor, J. W., Morgan, J. A. T., Vredenburg, V. T., et al. (2005). The novel and endemic pathogen hypothesis: competing explanations for the origin of emerging infectious diseases. Conserv. Biol. 19, 1441-1448. doi: 10.1111/j.1523-1739.2005.00255.x

Raffel, T. R., Michel, P. J., Sites, E. W., and Rohr, J. R. (2010). What drives chytrid infections in newt populations? Associations with substrate, temperature, and shade. EcoHealth 7, 526-536. doi: 10.1007/s10393-010-0358-2

Raffel, T. R., Rohr, J. R., Kiesecker, J. M., and Hudson, P. J. (2006). Negative effects of changing temperature on amphibian immunity under field conditions. Funct. Ecol. 20, 819-828. doi: 10.1111/j.1365-2435.2006.01159.x

Rakus, K., Ronsmans, M., and Vanderplasschen, A. (2017). Behavioral fever in ectothermic vertebrates. Dev. Comp. Immunol. 66, 84-91. doi: 10.1016/j.dci.2016.06.027

Ramsey, J. P., Reinert, L. K., Harper, L. K., Woodhams, D. C., and RollinsSmith, L. A. (2010). Immune defenses against Batrachochytrium dendrobatidis, a fungus linked to global amphibian declines, in the South African Clawed Frog, Xenopus laevis. Infect. Immun. 78, 3981-3992. doi: 10.1128/IAI. 00402-10

Retallick, R., McCallum, H., and Speare, R. (2004). Endemic infection of the amphibian chytrid fungus in a frog community post-decline. PLoS Biol. 2, 1-7. doi: 10.1371/journal.pbio.0020351

Retallick, R. W. R., and Miera, V. (2007). Strain differences in the amphibian chytrid Batrachochytrium dendrobatidis and non-permanent, sub-lethal effects of infection. Dis. Aquat. Org. 75, 201-207. doi: 10.3354/dao075201

Ribas, L., Li, M. S., Doddington, B. J., Robert, J., Seidel, J. A., Kroll, J. S., et al. (2009). Expression profiling the temperature-dependent amphibian response to infection by Batrachochytrium dendrobatidis. PLoS ONE 4:e8408. doi: 10.1371/journal.pone.0008408

Riley, K., Berry, O. F., and Roberts, J. D. (2013). Do global models predicting environmental suitability for the amphibian fungus, Batrachochytrium dendrobatidis, have local value to conservation managers? J. Appl. Ecol. 50, 713-720. doi: 10.1111/1365-2664.12091 
Robak, M. J., and Richards-Zawacki, C. L. (2018). Temperature-dependent effects of cutaneous bacteria on a frog's tolerance of fungal infection. Front. Microbiol. 9:410. doi: 10.3389/fmicb.2018.00410

Rödder, D., Kielgast, J., and Lötters, S. (2010). Future potential distribution of the emerging amphibian chytrid fungus under anthropogenic climate change. Dis. Aquat. Org. 92, 201-207. doi: 10.3354/dao02197

Rodríguez-Brenes, S., Rodriguez, D., Ibáñez, R., and Ryan, M. J. (2016). Spread of Amphibian Chytrid Fungus across Lowland Populations of Túngara Frogs in Panamá. PLoS ONE 11:e0155745. doi: 10.1371/journal.pone.0155745

Rohr, J. R., and Raffel, T. R. (2010). Linking global climate and temperature variability to widespread amphibian declines putatively caused by disease. Proc. Natl. Acad. Sci. U.S.A. 107, 8269-8274. doi: 10.1073/pnas.0912883107

Rojas, S., Richards, K., Jancovich, J. K., and Davidson, E. W. (2005). Influence of temperature on Ranavirus infection in larval salamanders Ambystoma tigrinum. Dis. Aquat. Org. 63, 95-100. doi: 10.3354/dao063095

Rollins-Smith, L. A. (2009). The role of amphibian antimicrobial peptides in protection of amphibians from pathogens linked to global amphibian declines. Biochim. Biophys. Acta 1788, 1593-1599. doi: 10.1016/j.bbamem.2009.03.008

Rollins-Smith, L. A., Ramsey, J. P., Pask, J. D., Reinert, L. K., and Woodhams, D. C. (2011). Amphibian immune defenses against chytridiomycosis: impacts of changing environments. Integr. Comp. Biol. 51, 552-562. doi: $10.1093 /$ icb/icr095

Rollins-Smith, L. A., Ramsey, J. P., Reinert, L. K., Woodhams, D. C., Livo, L. J., and Carey, C. (2009). Immune defenses of Xenopus laevis against Batrachochytrium dendrobatidis. Front. Biosci. 1, 68-91. doi: 10.2741/s8

Rollins-Smith, L. A., Woodhams, D. C., Reinert, L. K., Vredenburg, V. T., Briggs, C. J., Nielsen, P. F., et al. (2006). Antimicrobial peptide defenses of the mountain yellow-legged frog (Rana muscosa). Dev. Comp. Immunol. 30, 831-842. doi: 10.1016/j.dci.2005.10.005

Rowley, J. J. L., and Alford, R. A. (2013). Hot bodies protect amphibians against chytrid infection in nature. Sci. Rep. 3:1515. doi: 10.1038/srep01515

Sakata, N., Tamori, Y., and Wakahara, M. (2005). P450 aromatase expression in the temperature-sensitive sexual differentiation of salamander (Hynobius retardatus) gonads. Int. J. Dev. Biol. 49, 417-425. doi: 10.1387/ijdb.041916ns

Sauer, E. L., Fuller, R. C., Richards-Zawacki, C. L., Sonn, J., Sperry, J. H., and Rohr, J. R. (2018). Variation in individual temperature preferences, not behavioural fever, affects susceptibility to chytridiomycosis in amphibians. Proc. R. Soc. B 285:20181111. doi: 10.1098/rspb.2018.1111

Savage, A. E., and Zamudio, K. R. (2011). MHC genotypes associate with resistance to a frog-killing fungus. Proc. Natl. Acad. Sci. U.S.A. 108, 16705-16710. doi: $10.1073 /$ pnas. 1106893108

Savage, A. E., and Zamudio, K. R. (2016). Adaptive tolerance to a pathogenic fungus drives major histocompatibility complex evolution in natural amphibian populations. Proc. R. Soc. B 283:20153115. doi: 10.1098/rspb.2015.3115

Scheele, B. C., Dricoll, D. A., Fischer, J., Fletcher, A. W., Hanspach, J., Vörös, J., et al. (2015). Landscape context influences chytrid fungus distribution in an endangered European amphibian. Anim. Conserv. 18, 480-488. doi: 10.1111/acv.12199

Scheele, B. C., Hunter, D. A., Grogan, L. F., Berger, L., Kolby, J. E., McFadden, M. S., et al. (2014). Interventions for reducing extinction risk in chytridiomycosisthreatened amphibians. Conserv. Biol. 28, 1195-1205. doi: 10.1111/cobi.12322

Scheele, B. C., Pasmans, F., Skerratt, L. F., Berger, L., Martel, A., Beukema, W., et al. (2019). Amphibian fungal panzootic causes catastrophic and ongoing loss of biodiversity. Science 363, 1459-1463. doi: 10.1126/science. aav0379

Scheele, B. C., Skerratt, L. F., Grogan, L. F., Hunter, D. A., Clemann, N., McFadden, M., et al. (2017). After the epidemic: ongoing declines, stabilizations and recoveries in amphibians afflicted by chytridiomycosis. Biol. Conserv. 206, 37-46. doi: 10.1016/j.biocon.2016.12.010

Schmeller, D. S., Blooi, M., Martel, A., Garner, T. W. J., Fisher, M. C., Azemar, F., et al. (2014). Microscopic aquatic predators strongly affect infection dynamics of a globally emerged pathogen. Curr. Biol. 24, 176-180. doi: 10.1016/j.cub.2013.11.032

Schmidt, B. R., Hödl, W., and Schaub, M. (2012). From metamorphosis to maturity in complex life cycles: equal performance of different juvenile life history pathways. Ecology 93, 657-667. doi: 10.1890/11-0892.1
Searle, C. L., Mendelson, J. R. III, Green, L. E., and Duffy, M. A. (2013). Daphnia predation on the amphibian chytrid fungus and its impacts on disease risk in tadpoles. Ecol. Evol. 3, 4129-4138. doi: 10.1002/ece3.777

Semlitsch, R. D., Scott, D. E., and Pechmann, J. H. (1988). Time and size at metamorphosis related to adult fitness in Ambystoma talpoideum. Ecology 69, 184-192. doi: 10.2307/1943173

Sherman, E. (2008). Thermal biology of newts (Notophthalmus viridescens) chronically infected with a naturally occurring pathogen. J. Therm. Biol. 33, 27-31. doi: 10.1016/j.jtherbio.2007.09.005

Sherman, E., Baldwin, L., Fernandez, G., and Deurell, E. (1991). Fever and thermal tolerance in the toad Bufo marinus. J. Therm. Biol. 16, 297-301. doi: 10.1016/0306-4565(91)90021-S

Sherman, E., and Levitis, D. (2003). Heat hardening as a function of developmental stage in larval and juvenile Bufo americanus and Xenopus laevis. J. Therm. Biol. 28, 373-380. doi: 10.1016/S0306-4565(03)00014-7

Shoo, L. P., Olson, D. H., McMenamin, S. K., Murray, K. A., Van Sluys, M., Donnelly, M. A., et al. (2011). Engineering a future for amphibians under climate change. J. Appl. Ecol. 48, 487-492. doi: 10.1111/j.1365-2664.2010.01942.x

Skerratt, L. F., Berger, L., Speare, R., Cashins, S., McDonald, K. R., Phillott, A. D., et al. (2007). Spread of chytridiomycosis has caused the rapid global decline and extinction of frogs. EcoHealth 4, 125-134. doi: 10.1007/s10393-007-0093-5

Smith, D. C. (1987). Adult recruitment in chorus frogs: effects of size and date at metamorphosis. Ecology 68, 344-350. doi: 10.2307/1939265

Sonn, J. M., Berman, S., and Richards-Zawacki, C. L. (2017). The influence of temperature on chytridiomycosis in vivo. EcoHealth 14, 762-770. doi: 10.1007/s10393-017-1269-2

Spitzen-van der Sluijs, A., Martel, A., Asselberghs, J., Bales, E. K., Beukema, W., Bletz, M. C., et al. (2016). Expanding distribution of lethal amphibian fungus Batrachochytrium salamandrivorans in Europe. Emerg. Infect. Dis. 22, 1286-1288. doi: 10.3201/eid2207.160109

Spitzen-van der Sluijs, A., Spikmans, F., Bosman, W., de Zeeuw, M., van der Meij, T., Goverse, E., et al. (2013). Rapid enigmatic decline drives the fire salamander (Salamandra salamandra) to the edge of extinction in the Netherlands. Amphibia-Reptilia 34, 233-239. doi: 10.1163/15685381-00002891

Stegen, G., Pasmans, F., Schmidt, B. R., Rouffaer, L. O., Van Praet, S., Schaub, M., et al. (2017). Drivers of salamander extirpation mediated by Batrachochytrium salamandrivorans. Nature 544, 353-356. doi: 10.1038/nature22059

Stevenson, L. A., Alford, R. A., Bell, S. C., Roznik, E. A., Berger, L., and Pike, D. A. (2013). Variation in thermal performance of a widespread pathogen, the amphibian chytrid fungus Batrachochytrium dendrobatidis. PLoS ONE 8:e73830. doi: 10.1371/journal.pone.0073830

Stevenson, L. A., Roznik, E. A., Alford, R. A., and Pike, D. A. (2014). Hostspecific thermal profiles affect fitness of a widespread pathogen. Ecol. Evol. 4, 4053-4064. doi: 10.1002/ece3.1271

Stice, M. J., and Briggs, C. J. (2010). Immunization is ineffective at preventing infection and mortality due to the amphibian chytrid fungus Batrachochytrium dendrobatidis. J. Wildlife Dis. 46, 70-77. doi: 10.7589/0090-3558-46.1.70

Stockwell, M. P., Storrie, L. J., Pollard, C. J., Clulow, J., and Mahony, M. J. (2015). Effects of pond salinization on survival rate of amphibian hosts infected with the chytrid fungus. Conserv. Biol. 29, 391-399. doi: 10.1111/cobi.12402

Stuart, S. N., Chanson, J. S., Cox, N. A., Young, B. E., Rodrigues, A. S. L., Fischman, D. L., et al. (2004). Status and trends of amphibian declines and extinctions worldwide. Science 306, 1783-1786. doi: 10.1126/science.1103538

Studer, A., Thieltges, D., and Poulin, R. (2010). Parasites and global warming: net effects of temperature on an intertidal host-parasite system. Mar. Ecol. Prog. Ser. 415, 11-22. doi: 10.3354/meps08742

Sunday, J. M., Bates, A. E., and Dulvy, N. K. (2014a). Global analysis of thermal tolerance and latitude in ectotherms. Proc. R. Soc. B 278, 1823-1830. doi: $10.1098 /$ rspb.2010.1295

Sunday, J. M., Bates, A. E., Kearney, M. R., Colwell, R. K., Dulvy, N. K., Longino, J. T., et al. (2014b). Thermal-safety margins and the necessity of thermoregulatory behavior across latitude and elevation. Proc. Natl. Acad. Sci. U.S.A. 111, 5610-5615. doi: 10.1073/pnas.1316145111

Thieltges, D. W., and Rick, J. (2006). Effect of temperature on emergence, survival and infectivity of cercariae of the marine trematode Renicola roscovita (Digenea: Renicolidae). Dis. Aquat. Org. 73, 63-68. doi: 10.3354/dao073063 
Tinsley, R. C., York, J. E., Everard, A. L. E., Stott, L. C., Chapple, S. J., and Tinsley, M. C. (2011). Environmental constraints influencing survival of an African parasite in a north temperate habitat: effects of temperature on egg development. Parasitology 138, 1029-1038. doi: 10.1017/S0031182011000461

Tobler, U., Borgula, A., and Schmidt, B. R. (2012). Populations of a susceptible amphibian species can grow despite the presence of a pathogenic chytrid fungus. PLoS ONE 7:e34667. doi: 10.1371/journal.pone.0034667

Tobler, U., and Schmidt, B. R. (2010). Within- and among-population variation in chytridiomycosis-induced mortality in the toad Alytes obstetricans. PLoS ONE 5:e10927. doi: 10.1371/journal.pone.0010927

Turriago, J. L., Parra, C. A., and Bernal, M. H. (2015). Upper thermal tolerance in anuran embryos and tadpoles at constant and variable peak temperatures. Can. J. Zool. 93, 267-272. doi: 10.1139/cjz-2014-0254

Ultsch, G. R., Bradford, D. F., and Freda, J. (1999). "Physiology: coping with the environment," in Tadpoles: The Biology of Anuran Larvae, eds R. W. McDiarmid and R. Altig (Chicago, IL: University of Chicago Press), 189-214.

Van Rooij, P., Martel, A., Haesebrouck, F., and Pasmans, F. (2015). Amphibian chytridiomycosis: a review with focus on fungus-host interactions. Vet. Res. 46:137. doi: 10.1186/s13567-015-0266-0

Voyles, J., Johnson, L. R., Rohr, J., Kelly, R., Barron, C., Miller, D., et al. (2017). Diversity in growth patterns among strains of the lethal fungal pathogen Batrachochytrium dendrobatidis across extended thermal optima. Oecologia 184, 363-373. doi: 10.1007/s00442-017-3866-8

Voyles, J., Woodhams, D. C., Saenz, V., Byrne, A. Q., Perez, R., Riossotelo, G., et al. (2018). Shifts in disease dynamics in a tropical amphibian assemblage are not due to pathogen attenuation. Science 359, 1517-1519. doi: 10.1126/science.aao4806

Voyles, J., Young, S., Berger, L., Campbell, C., Voyles, W. F., Dinudom, A., et al. (2009). Pathogenesis of chytridiomycosis, a cause of catastrophic amphibian declines. Science 326, 582-585. doi: 10.1126/science.1176765

Vredenburg, V. T., Knapp, R. A., Tunstall, T. S., and Briggs, C. J. (2010). Dynamics of an emerging disease drive large-scale amphibian population extinctions. Proc. Natl. Acad. Sci. U.S.A. 107, 9689-9694. doi: 10.1073/pnas.0914111107

Wake, D. B., and Vredenburg, V. T. (2008). Are we in the midst of the sixth mass extinction? A view from the world of amphibians. Proc. Natl. Acad. Sci. U.S.A. 105, 11466-11473. doi: 10.1073/pnas.0801921105

Walker, S. F., Bosch, J., Gomez, V., Garner, T. W. J., Cunningham, A. A., Schmeller, D. S., et al. (2010). Factors driving pathogenicity vs. prevalence of amphibian panzootic chytridiomycosis in Iberia. Ecol. Lett. 13, 372-382. doi: 10.1111/j.1461-0248.2009.01434.x

Wallace, H., Badawy, G. M. I., and Wallace, B. M. N. (1999). Amphibian sex determination and sex reversal. Cell Mol. Life Sci. 55, 901-909. doi: $10.1007 / \mathrm{s} 000180050343$

Wallace, H., and Wallace, B. M. N. (2000). Sex reversal of the newt Triturus cristatus reared at extreme temperatures. Int. J. Dev. Biol. 44, 807-810.

Weldon, C., du Preez, L. H., Hyatt, A. D., Muller, R., and Spears, R. (2004). Origin of the amphibian chytrid fungus. Emerg. Infect. Dis. 10, 2100-2105. doi: 10.3201/eid1012.030804

Wells, K. D. (2007). The Ecology and Behavior of Amphibians. Chicago, IL: The University of Chicago Press.

White, A. W. (2006). A trial using salt to protect green and golden bell frogs from chytrid infection. Herpetofauna 36, 93-96.
Whitfield, S. M., Geerdes, E., Chacon, I., Ballestero Rodriguez, E., Jimenez, R. R., Donnelly, M. A., et al. (2013). Infection and co-infection by the amphibian chytrid fungus and ranavirus in wild Costa Rican frogs. Dis. Aquat. Org. 104, 173-178. doi: 10.3354/dao02598

Wilbur, H. M. (1980). Complex life cycles. Annu. Rev. Ecol. Syst. 11, 67-93. doi: 10.1146/annurev.es.11.110180.000435

Woodhams, D. C., and Alford, R. A. (2005). Ecology of chytridiomycosis in rainforest stream frog assemblages of tropical Queensland. Conserv. Biol. 19, 1449-1459. doi: 10.1111/j.1523-1739.2005.004403.x

Woodhams, D. C., Alford, R. A., Briggs, C. J., Johnson, M., and Rollins-Smith, L. A. (2008). Life-history trade-offs influence disease in changing climates: strategies of an amphibian pathogen. Ecology 89, 1627-1639. doi: 10.1890/06-1842.1

Woodhams, D. C., Alford, R. A., and Marantelli, G. (2003). Emerging disease of amphibians cured by elevated body temperature. Dis. Aquat. Org. 55, 65-67. doi: 10.3354/dao055065

Woodhams, D. C., Ardipradja, K., Alford, R. A., Marantelli, G., Reinert, L. K., and Rollins-Smith, L. A. (2007a). Resistance to chytridiomycosis varies among amphibian species and is correlated with skin peptide defenses. Anim. Conserv. 10, 409-417. doi: 10.1111/j.1469-1795.2007.00130.x

Woodhams, D. C., Bosch, J., Briggs, C. J., Cashins, S., Davis, L. R., Lauer, A., et al. (2011). Mitigating amphibian disease: strategies to maintain wild populations and control chytridiomycosis. Front. Zool. 8:8. doi: 10.1186/17429994-8-8

Woodhams, D. C., Geiger, C. C., Reinert, L. K., Rollins-Smith, L. A., Lam, B., Harris, R. N., et al. (2012). Treatment of amphibians infected with chytrid fungus: learning from failed trials with itraconazole, antimicrobial peptides, bacteria, and heat therapy. Dis. Aquat. Org. 98, 11-25. doi: 10.3354/dao02429

Woodhams, D. C., Vredenburg, V. T., Simon, M.-A., Billheimer, D., Shakhtour, B., Shyr, Y., et al. (2007b). Symbiotic bacteria contribute to innate immune defenses of the threatened mountain yellow-legged frog, Rana muscosa. Biol. Conserv. 138, 390-398. doi: 10.1016/j.biocon.2007.05.004

Woodward, A., Berger, L., and Skerratt, L. F. (2014). In vitro sensitivity of the amphibian pathogen Batrachochytrium dendrobatidis to antifungal therapeutics. Res. Vet. Sci. 97, 365-367. doi: 10.1016/j.rvsc.2014. 06.013

Zippel, K., Johnson, K., Gagliardo, R., Gibson, R., McFadden, M., Browne, R., et al. (2011). The amphibian ark: a global community for ex situ conservation of amphibians. Herpetol. Conserv. Biol. 6, 340-352.

Conflict of Interest Statement: The authors declare that the research was conducted in the absence of any commercial or financial relationships that could be construed as a potential conflict of interest.

The handling editor declared a past co-authorship with one of the authors, BS.

Copyright (C) 2019 Hettyey, Ujszegi, Herczeg, Holly, Vörös, Schmidt and Bosch. This is an open-access article distributed under the terms of the Creative Commons Attribution License (CC BY). The use, distribution or reproduction in other forums is permitted, provided the original author(s) and the copyright owner(s) are credited and that the original publication in this journal is cited, in accordance with accepted academic practice. No use, distribution or reproduction is permitted which does not comply with these terms. 